\title{
Piperlongumine Analogs Promote A549 Cell Apoptosis through Enhancing ROS Generation
}

\author{
Ai-Ling Sun ${ }^{1,+}$, Wen-Wen Mu ${ }^{2, \dagger}$, Yan-Mo Li ${ }^{3}$, Ya-Lei Sun ${ }^{4}$, Peng-Xiao Li ${ }^{2}$, Ren-Min Liu ${ }^{2}$, Jie Yang ${ }^{2, *}$ \\ and Guo-Yun Liu 2,*(D) \\ 1 School of Chemistry and Chemical Engineering, Liaocheng University, Liaocheng 252059, China; \\ sunailing1985@126.com \\ 2 School of Pharmaceutical Sciences, Liaocheng University, Liaocheng 252059, China; \\ MWW1115@163.com (W.-W.M.); Lipx19986@163.com (P.-X.L.); liurenmin@lcu.edu.cn (R.-M.L.) \\ 3 Shandong Center for Disease Control and Prevention, Jinan 250014, China; liyanmo163@163.com \\ 4 Qingdao Vland Biotech INC, Qingdao 266000, China; sunyl01@vlandgroup.com \\ * Correspondence: yangjie1110@163.com (J.Y.); guoyunliu@126.com (G.-Y.L.) \\ + The authorship contributed equally to this work.
}

check for

updates

Citation: Sun, A.-L.; Mu, W.-W.;

Li, Y.-M.; Sun, Y.-L.; Li, P.-X.;

Liu, R.-M.; Yang, J.; Liu, G.-Y.

Piperlongumine Analogs Promote

A549 Cell Apoptosis through

Enhancing ROS Generation. Molecules

2021, 26, 3243. https://doi.org/

$10.3390 /$ molecules 26113243

Academic Editors: Antonino Lauria

and Annamaria Martorana

Received: 13 April 2021

Accepted: 27 May 2021

Published: 28 May 2021

Publisher's Note: MDPI stays neutral with regard to jurisdictional claims in published maps and institutional affiliations.

Copyright: (c) 2021 by the authors. Licensee MDPI, Basel, Switzerland. This article is an open access article distributed under the terms and conditions of the Creative Commons Attribution (CC BY) license (https:/ / creativecommons.org/licenses/by/ $4.0 /)$.

\begin{abstract}
Chemotherapeutic agents, which contain the Michael acceptor, are potent anticancer molecules by promoting intracellular reactive oxygen species (ROS) generation. In this study, we synthesized a panel of PL (piperlongumine) analogs with chlorine attaching at C2 and an electronwithdrawing/electron-donating group attaching to the aromatic ring. The results displayed that the strong electrophilicity group at the C2-C3 double bond of PL analogs plays an important role in the cytotoxicity whereas the electric effect of substituents, which attached to the aromatic ring, partly contributed to the anticancer activity. Moreover, the protein containing sulfydryl or seleno, such as TrxR, could be irreversibly inhibited by the C2-C3 double bond of PL analogs, and boost intracellular ROS generation. Then, the ROS accumulation could disrupt the redox balance, induce lipid peroxidation, lead to the loss of MMP (Mitochondrial Membrane Potential), and ultimately result in cell cycle arrest and A549 cell line death. In conclusion, PL analogs could induce in vitro cancer apoptosis through the inhibition of TrxR and ROS accumulation.
\end{abstract}

Keywords: piperlongumine an alog; michael acceptor; anticancer activity; reactive oxygen species; thioredoxin reductase

\section{Introduction}

Natural products have been markedly studied for drug discovery, including anti-inflammatory agents [1], anti-bacterial agents [2], and particularly anti-cancer agents [3,4]. Piperlongumine (PL), a natural alkaloid isolated from traditional Chinese medicine Piper longum L., is well known to possess multiple pharmacological effects, such as anti-microbial [5], anti-Parkinsonian [6] and anti-epileptic [7] effects. So far, hundreds of publications have shown that PL could exhibit anticancer activities in various cancer cells [8,9], and effectively inhibit tumor growth without considerable side effects in tumor xenograft models [10]. Moreover, PL induces cell cycle arrest and death of A549 cells through triggering reactive oxygen species (ROS) accumulation in cancer cells [11,12].

ROS, well known as an upstream signal involved in the induction of cancer cell death, can be triggered by several exogenous and endogenous factors $[13,14]$. ROS induced by chemotherapeutic agents may be mainly due to the inhibition of the antioxidant system. For example, curcumin [15] and PL [16], characterized with the Michael acceptor, could irreversibly inhibit thioredoxin reductase ( $\operatorname{TrxR})$, and the adduct triggers ROS generation. The electrophilicity of Michael acceptor units is important for the TrxR inhibition and ROS generation ability [17]. Yan and co-workers have designed piperlongumine-directed anticancer agents by an electrophilicity-based prooxidant strategy [16]. The structure-activity relationship of PL analogs reveals that C2-C3 and C7-C8 double bonds are essential for their 
cytotoxicity against cancer cells [18] (Scheme 1). C2-C3 double bond plays a critical role in the ROS generation and glutathione lessening whereas C7-C8 double bonds are partially correlated with the anti-proliferative activity of $\mathbf{P L}$, and the effect of the pharmacophore on anticancer activity remains unexplored.

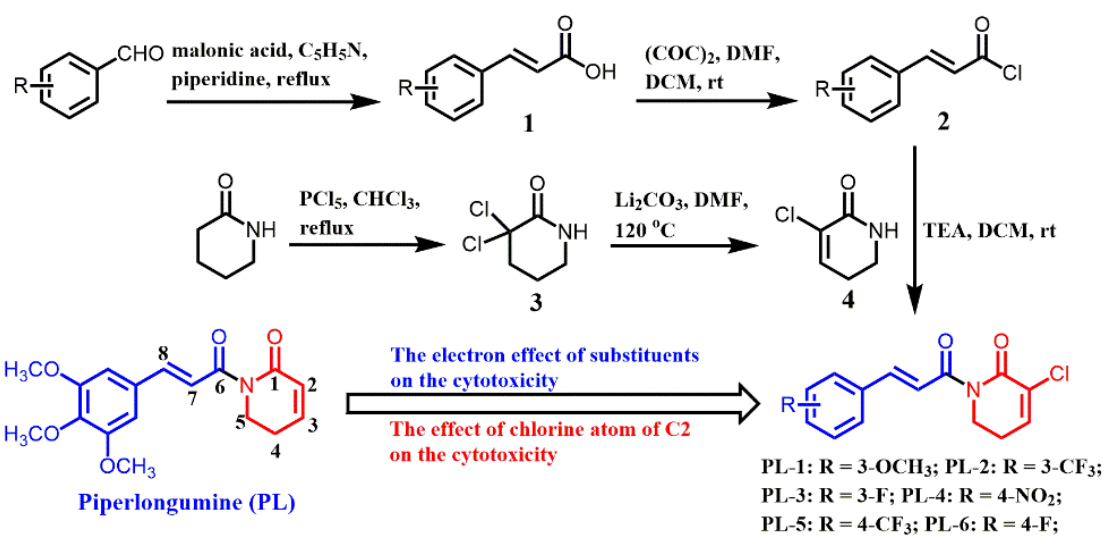

Scheme 1. The synthetic routs of piperlongumine (PL) analogs.

Additionally, fluorine, which usually presents in drugs, exihits a variety of properties to certain medicines, such as increased metabolic stability, binding interactions, selective reactivities and so on [19]. Considering the aforementioned, we synthesized a panel of $\mathrm{PL}$ analogs with electron-withdrawing group $\left(-\mathrm{F}\right.$ and $\left.\mathrm{CF}_{3}\right)$ or electron-donating group $\left(-\mathrm{OCH}_{3}\right)$ attaching to the aromatic ring (Scheme 1). Then, we studied the electronic effect of substituents on the cytotoxicity and explored the anticancer mechanism of PL analogs against A549 cells.

\section{Results}

\subsection{Chemistry}

The synthetic routes of PL analogs are illustrated in Scheme 1. The intermediate 4 (3chloro-5,6-dihydropyridin-2(1H)-one) was obtained from commercial 2-piperidone through two steps, including $\alpha$-halogenation and elimination. Then, the appropriate cinnamoyl chloride 2, condensing between benzaldehyde and malonic acid, reacted with intermediate 4 through a nucleophilic substitution reaction to afford the target comounds with lower yields. All compounds were characterized by nuclear magnetic resonance $\left({ }^{1} \mathrm{H}-\mathrm{NMR}\right)$ and ${ }^{13} \mathrm{C}-\mathrm{NMR}$.

\subsection{Assessment of In Vitro Cytotoxicity}

PL analogs 1-6 were determined for their cytotoxicity aganinst A549 and SKOV3 cells by MTT (3-(4,5-Dimethylthiazol-2-yl)-2,5-diphenyltetrazolium bromide) assay. As illustrated in Table 1, most of the PL analogs were more excellent or equivalent to PL against cancer cells, and the cytotoxicity order as the follows: PL-6 > PL-1 > PL PL-5 PL-2. This result indicated that the electron-withdrawing group (chlorine) attached to C2 could strengthen the antiproliferative activity of PL analogs. Moreover, the outstanding cytotoxicity of PL-2, PL-5 and PL-6 may be attributed to the electron-withdrawing effect of $-\mathrm{F}$ and $-\mathrm{CF}_{3}$, which could heighten the electrophilicity of the $\mathrm{C} 7-\mathrm{C} 8$ double bond. Additionally, PL-2, PL analogs were stable in phosphate-buffered saline (PBS) buffer at $25^{\circ} \mathrm{C}$ (Figure 1). PL-1 and PL-6 showed the strongest antiproliferative activity against A549 cells among these compounds and, therefore, we focused on A549 cells to investigate the cytotoxic mechanism of PL-1 and PL-6 in subsequent experiments. 
Table 1. Cytotoxicity of PL and its analogs against A549and SK-OV3 cells.

\begin{tabular}{|c|c|c|c|c|c|}
\hline \multirow{6}{*}{ Comps. } & \multicolumn{2}{|c|}{$\mathrm{IC}_{50} /(\mu \mathrm{M})$} & \multirow{2}{*}{ Comps. } & \multicolumn{2}{|c|}{$\mathrm{IC}_{50} /(\mu \mathrm{M})$} \\
\hline & A549 & SK-OV3 & & A549 & SK-OV3 \\
\hline & $4.3 \pm 0.2$ & $12.6 \pm 1.4$ & & $8.5 \pm 0.3$ & $15.4 \pm 0.8$ \\
\hline & $7.73 \pm 0.1$ & $23.2 \pm 1.7$ & & $3.3 \pm 0.2$ & $18.5 \pm 1.4$ \\
\hline & $>200$ & $>200$ & & $7.9 \pm 0.8$ & $19.4 \pm 1.7$ \\
\hline & $19.6 \pm 1.9$ & $34.8 \pm 2.8$ & & & \\
\hline
\end{tabular}

The $\mathrm{IC}_{50}$ value is the concentration of a compound tested to cause $50 \%$ inhibition of cell viability after $48 \mathrm{~h}$ of treatment, and is expressed as the mean $\pm \mathrm{SD}$ for three determinations.

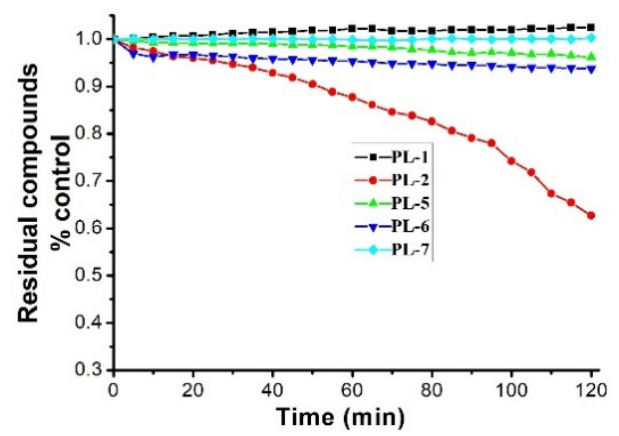

Figure 1. The stabilities of PL analogs (50 $\mu \mathrm{M})$ in phosphate-buffered saline (PBS) buffer (100 mM) at $25^{\circ} \mathrm{C}$.

\subsection{Piperlongumine (PL) Analogs Triggered Cell Cycle Arrest}

In order to explore the effects of PL analogs (PL-1 and PL-6) on cell cycle arrest, flow cytometry was used to determine the cell cycle distribution. As shown in Figure 2, PL-1 and PL-6 obviously reduced the percentage of cells in G0/G1 phase, and enhanced the percentage of cells in G2/M phase in a dose-dependent fashion, relative to the control group. Moreover, PL-1 and PL-6 were excellent or equivalent to PL on the cell cycle arrest of A549 cells; $30 \mu \mathrm{M}$ PL-6 led $36.4 \%$ percentage of cells in the G2/M phase. In addition, the classic antioxidant-NAC ( $N$-Acetyl- $L$-cysteine) could effectively inhibit the cell cycle arrest activity induced by PL-1 and PL-6. This result hinted that PL-1 and PL-6 may induce A549 cells cycle arrest via ROS generation.

\subsection{The Apoptotic Effects of PL Analogs against the A549 Cell}

Next, we tested the apoptosis-inducing activity of PL analogs (PL-1 and PL-6) on A549 cells using a flow cytometry cell apoptosis assay. As illustrated in Figure 3, PL-1 and PL-6 exhibited more outstanding cell death-inducing capacity against A549 cells compared to PL, and emerged in an excellent dose-dependent manner. The late apoptosis of A549 cells induced by PL-1 $(30 \mu \mathrm{M})$ and PL-6 $(30 \mu \mathrm{M})$ were $38.9 \%$ and $37.8 \%$, respectively. Additionally, the apoptosis-inducing activities of PL-1 $(30 \mu \mathrm{M})$ and PL-6 $(30 \mu \mathrm{M})$ were remarkably reduced by pretreatment with NAC. This result also implied that PL-1 and PL-6 may induce cell death of A549 cells through ROS production. 

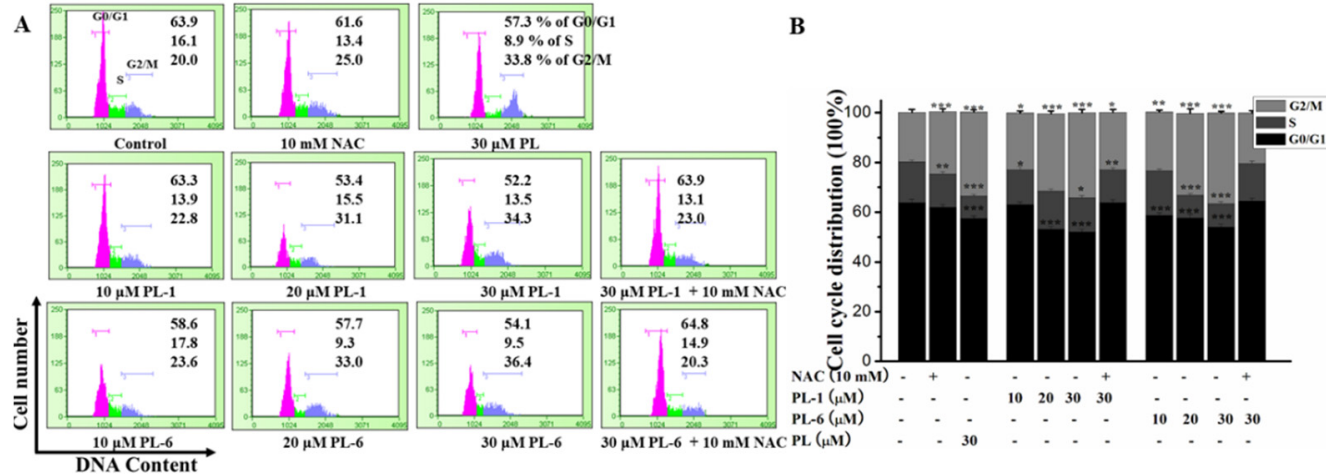

B

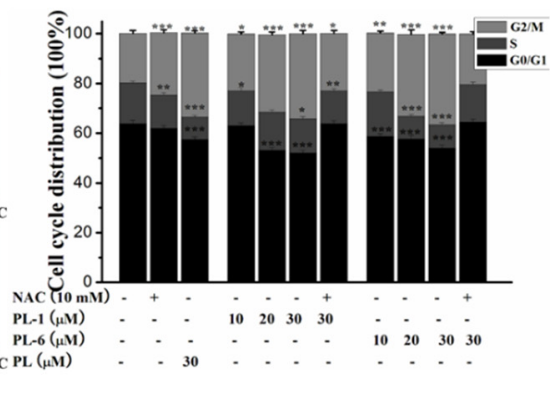

Figure 2. The effect of PL analogs (PL-1 and PL-6) on the cell cycle arrest of A549 cells at the in dicated concentrations in the presence or absence of NAC. (A) The cell cycle distribution of the cells was analyzed, and the percentage of cells within G0/G1, S and G2/M phase was indicated in every diagram. (B) The quantitative analysis was demonstrated as histograms. ${ }^{*} p<0.05,{ }^{* *} p<0.01,{ }^{* * *} p<0.001$ compared with control.
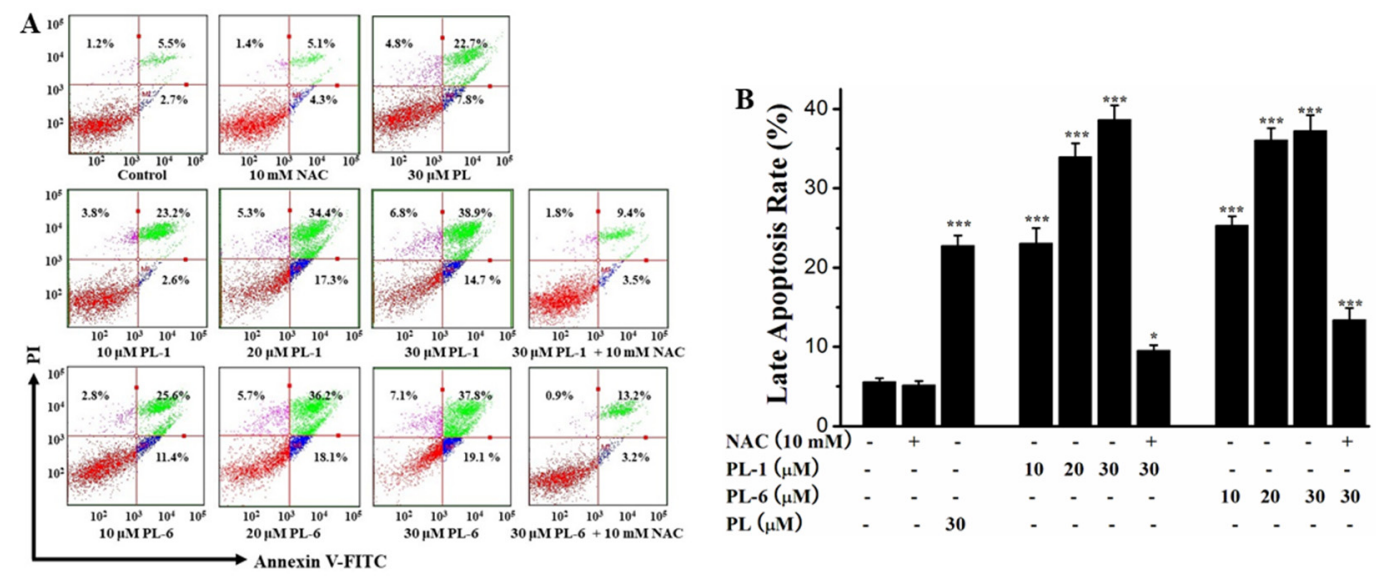

Figure 3. The apoptotic effects of PL analogs (PL-1 and PL-6) against the A549 cells at the indicated concentrations in the presence or absence of NAC. (A) The cell apoptosis of A549 cells was analyzed. (B) The quantitative analysis was demonstrated as histograms. ${ }^{*} p<0.05,{ }^{* * *} p<0.001$ compared with control.

\subsection{PL Analogs Induced Reactive Oxygen Species (ROS) Generation and Redox Imbalance}

Based on the Figure 3 results, we measured whether PL-1 and PL-6 could trigger ROS generation in A549 cells. A DCFH-DA $\left(2^{\prime}, 7^{\prime}\right.$-dichlorofluorescein diacetate) probe was used to test the changes of ROS levels in A549 cells. The results indicated that PL-1 and PL-6 remarkably increased the ROS levels compared to the control group, and displayed a dose-dependent relationship (Figure 4A). Moreover, the ROS generation abilities of PL-1 and PL-6 were much stronger than the leading PL; $30 \mu \mathrm{M}$ PL-6 resulted in a 2.7-fold increase of ROS levels compared to the control group. In addition, NAC could sharply decrease the ROS induced by PL-1 $(30 \mu \mathrm{M})$ and PL-6 $(30 \mu \mathrm{M})$ (Figure 4A). The ROS accumulation could cause intracellular oxidative stress. Therefore, the ratios of GSH/GSSG (Glutathione/L-Glutathione Oxidized) were measured according to the glutathione reductase-DTNB recycling assay. As shown in Figure 4B, PL analogs obviously decreased the ratios of GSH/GSSG in a dose-dependent fashion. $30 \mu \mathrm{M}$ PL-6 caused a 5 -fold decrease of the ratio of GSH/GSSG relative to the control group. In particular, the redox imbalance induced by PL-1 $(30 \mu \mathrm{M})$ and PL-6 $(30 \mu \mathrm{M})$ were prevented significantly by NAC. These results suggest that $\mathbf{P L}$ analogs can trigger ROS accumulation and induce redox imbalance of A549 cells. 

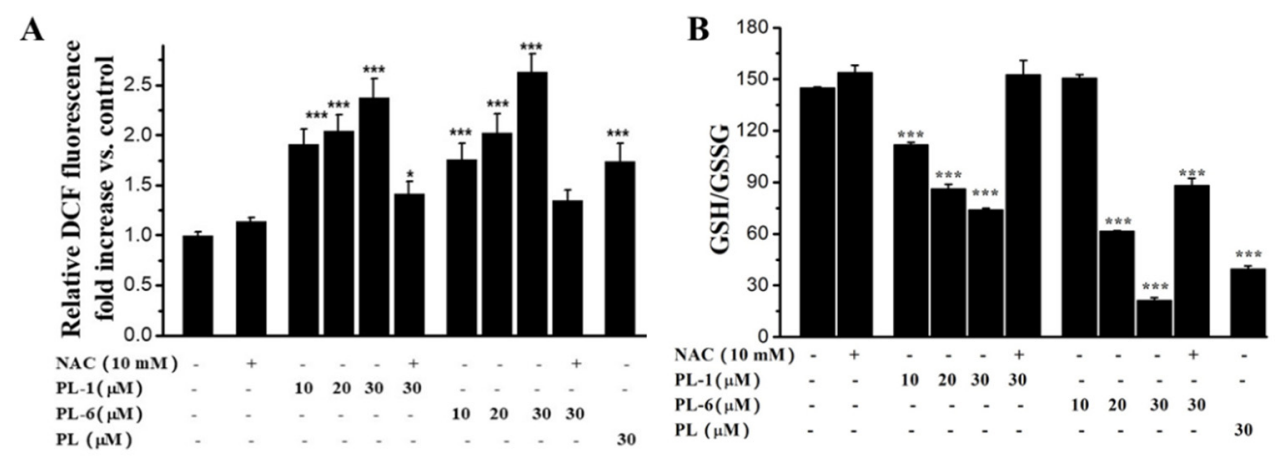

Figure 4. The effects of PL analogs (PL-1 and PL-6) on the ROS generation (A) and redox imbalance (B) of A549 cells at the indicated concentrations in the presence or absence of NAC. ${ }^{*} p<0.05,{ }^{* * *} p<0.001$ compared with control.

\subsection{PL Analogs Induced Lipid Peroxidation and the Loss of MMP (Mitochondrial Membrane Potential)}

Since the ROS accumulation could induce the lipid peroxidation of cell membrane, we measured the MDA (Malondialdehyde) levels of A549 cell after treatment with PL analogs. We found that both PL-1 and PL-6 led the increase of MDA levels (Figure 5A). The MDA levels induced by PL-1 $(30 \mu \mathrm{M})$ and PL-6 $(30 \mu \mathrm{M})$ were higher than that of PL. This result was in accordance with their apoptosis-inducing activities and ROS generation abilities against the A549 cells. In addition, the lipid peroxidation induced by PL-1 (30 $\mu \mathrm{M})$ and PL-6 $(30 \mu \mathrm{M})$ were fundamentally inhibited by pretreatment with NAC (Figure 5A). In addition, both PL-1 and PL-6 resulted in the loss of MMP in a dose-dependent manner. PL-6 (30 $\mu \mathrm{M})$ led to about a 10-fold decrease of MMP (mitochondrial membrane potential) compared with the control group, and was more active than that of PL $(30 \mu \mathrm{M})$. The loss of MMP can be significantly blocked NAC (Figure 5B). These results indicated that PL analogs could trigger ROS production, then induce redox imbalance, lipid peroxidation, the loss of MMP, cell cycle arrest and A549 cell line cell death.
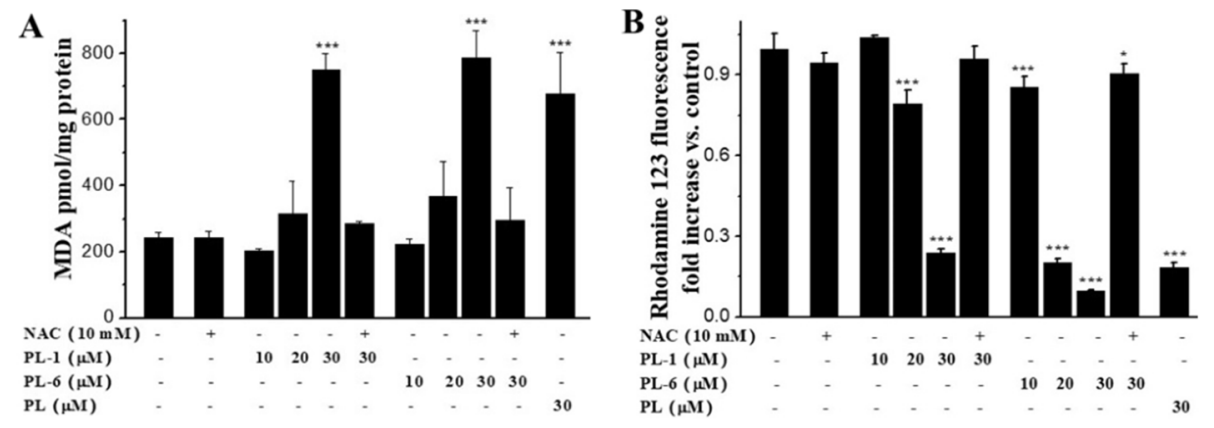

Figure 5. The effects of PL analogs (PL-1 and PL-6) on the lipid peroxidation (A) and the loss of MMP (B) of A549 cells at the indicated concentrations in the presence or absence of NAC. ${ }^{*} p<0.05$, $* * * p<0.001$ compared with control.

\subsection{The Nucleophilic Addition Reaction of PL Analogs and Cysteamine}

Figure 4 indicates that PL analogs triggered ROS generation, which can emerge through the reaction between thioredoxin reductase (TrxR) and chemotherapeutic agents containing the Michael acceptor. Therefore, we determined the electrophilicity of the Michael acceptor of PL analogs under pseudo-first-order conditions. As shown in Table 2, PL-1 and PL-6 exhibited much stronger electrophilicity than PL with $k_{2}$ value of 5.70 and $8.96 \mathrm{M}^{-1} \mathrm{~S}^{-1}$, in line with their cytotoxicity and ROS generation ability. 
Table 2. Second-order rate constants $\left(k_{2}\right)$ for the reaction of PL and its active analogs with cysteamine at $25^{\circ} \mathrm{C}$.

\begin{tabular}{cccc}
\hline Comps. & $\boldsymbol{k}_{\mathbf{2}}\left(\mathbf{M}^{-\mathbf{1}} \mathbf{s}^{-\mathbf{1}}\right)$ & Comps. & $\boldsymbol{k}_{\mathbf{2}}\left(\mathbf{M}^{-\mathbf{1}} \mathbf{s}^{-\mathbf{1}}\right)$ \\
\hline PL-1 & $5.70 \pm 0.24$ & PL-6 & $8.96 \pm 0.04$ \\
PL & $2.26 \pm 0.04$ & &
\end{tabular}

Reactions were carried out in Tris-HCl (100 mM, pH 7.4) and EDTA (2 mM, Ethylene Diamine Tetraacetic Acid)-ethanol $(v / v, 2 / 1)$ under pseudo-first-order conditions. Data are expressed as the mean \pm SD for three determinations.

In addition, we monitored the reaction of PL-6 and cysteamine in $d_{6}$-DMSO (Dimethyl$\mathrm{d}_{6}$ sulfoxide) using an NMR spectrometer. As shown in Figure 6A, the doublet of doublets at $\delta 7.731$ (H-1 and $\left.\mathrm{H}-1^{\prime}\right)$, calibrating to 2.00 hydrogen, was the protons of the aromatic nucleus. After incubating a mixture of PL-6 and cysteamine for $1 \mathrm{~h}$, the triplet integral at $\delta 7.332$, the olefinic proton of lactam $(\mathrm{H}-3)$, decreased to 0.46 compared to the ${ }^{1} \mathrm{H}-\mathrm{NMR}$ of PL-6 (Table 3). This phenomenon displayed that the Michael acceptor of lactam of PL analogs was the major reaction site of cysteamine. This result also hinted that the ROS generation induced by PL analogs was mainly due to the Michael acceptor of lactam. Moreover, after incubating PL-6 and cysteamine for 3 days, the 1:1 adduct $(m / z: 374.3040)$ was formed as exhibited in high-resolution mass spectrometry (HRMS) (Figure 6B).

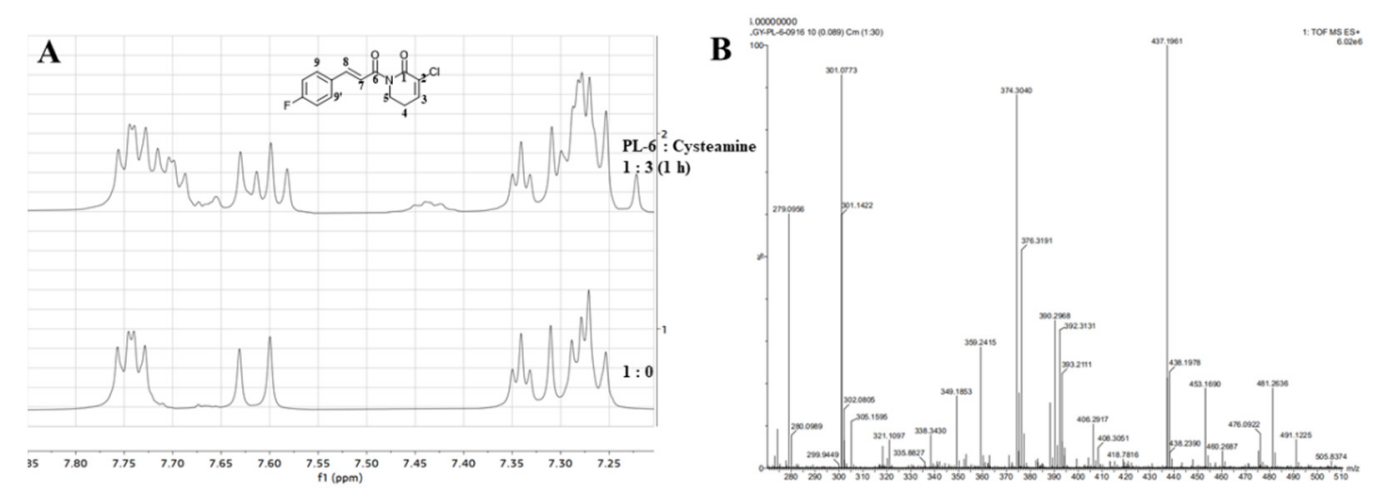

Figure 6. Reaction of PL-6 with cysteamine: (A) nuclear magnetic resonance ( ${ }^{1} \mathrm{H}$ NMR) spectra of PL in $d_{6}$-DMSO before and after adding cysteamine; (B) high-resolution mass spectrometry (HRMS) spectrum recorded 3 days after mixing PL-6 with 3 eq. of cysteamine.

Table 3. Quantification of the analytes after the addition of cysteamine.

\begin{tabular}{cccccc}
\hline Signals Assigned & Chemical Shift (ppm) & Coupled Splitting & Coupling Constants (J/Hz) & Time (h) & Integral \\
\hline H-9 & 7.731 & $\mathrm{dd}$ & 8.5 & 0 & 2.00 \\
H-9' & $7.658-7.759$ & $\mathrm{~m}$ & $/$ & 4.5 & 0 \\
H-3 & 7.332 & $\mathrm{t}$ & 4.5 & 1 & 1.00 \\
& 7.332 & $\mathrm{t}$ & 0.46 \\
\hline
\end{tabular}

\subsection{The Inhibition Activity of PL-6 on TrxR}

In the the results in Figures 3 and 4 and Table 3, we demonstrate that PL analogs reacted with cysteamine, and induced A549 cell line cells death through triggering ROS generation, which can be obtained by the inhibition of TrxR. In order to confirm the ROS production induced by PL-6 was related to TrxR, we analyzed the expression of TrxR in A549 cells using a Western blot assay. As shown in Figure 7, the TrxR expression was decreased in a dose-dependent fashion. Moreover, the down-regulation of TrxR induced by PL- 6 can be reduced by NAC. This result was in line with the ROS generation and death of A549 cells induced by PL-6. 


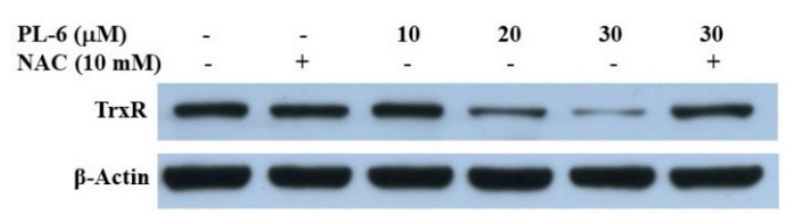

Figure 7. Western blot analysis of TrxR protein in A549 cells treated with PL-6 for $18 \mathrm{~h}$ in the absence or presence of pretreatment with NAC.

\section{Discussion}

Cancer, one of the major causes of morbidity and mortality in the world, is becoming a primary concern of human health. Chemotherapeutic agents, commonly applied in cancer diagnosis and treatment [20], could inhibit proliferation or induce cancer cell death through various molecular pathways, such as nuclear factor- $\mathrm{kB}$ (NF-kB) [21], vascular endothelial growth factors [22], PI3/Akt [23] and so on. In particular, the ROS, which also induce cancer cell apoptosis, can be triggered by chemotherapeutic agents containing the Michael acceptor units [16]. TrxR can be irreversibly inhibited by the Michael acceptor of chemotherapeutic agents and the modified enzyme converted into a prooxidant that triggered ROS generation [15]. PL, as one of the simplest alkaloids found in Piper longum L., contains two Michael acceptor units and has been used for the purpose of cancer prevention and treatment [17].

In this work, we obtained a panel of $\mathbf{P L}$ analogs via a nucleophilic substitution reaction between intermediate 2 and 4 , and found that the strong electrophilicity of the C2-C3 double bond was to the benefit of enhancing the cytotoxicity of PL analogs against cancer cells (Table 1). Moreover, the cinnamic acid unit, with strong electron-withdrawing or weak electron-donating groups, partly contribute to the anticancer activity of PL analogs. The results illustrated that the Michael acceptor of lactam plays a major role in the antiproliferative activity. The Michael acceptor unit can be attacked by nucleophiles, such as TrxR, GSH and so on, and results in the ROS generation [15]. TrxR of A549 cells can be inhibited by PL-6 which also confirmed this phenomenon (Figure 7). We further identified that cysteamine mainly reacted with the Michael acceptor of lactam by the ${ }^{1} \mathrm{H}-\mathrm{NMR}$ and HRMS (Figure 6, Table 3).

The irreversible inhibition of TrxR by chemotherapeutic agents resulted in the ROS accumulation, which is linked to numerous biological processes and disease conditions [13]. Cancer cells exhibited a greater ROS level than normal cells [24]. Therefore, a common therapeutic strategy that increases ROS generation may force cancer cells to surpass the redox balance, leading to the activation of different cell death pathway [24]. For example, ROS acculumation can induce cancer cells death. As illustrated in Figure 4A, PL analogs displayed better activity by triggering ROS generation than that of PL. In addition, ROS acculumation altered the redox status, which were significantly inhibited by NAC (Figure 4B). Redox imbalance in turn influenced the production of ROS. Moreover, ROS can directly oxidize cell membrane and lead to the increase of MDA levels (Figure 5A). Generous ROS also executed cancer cell apoptosis in a mitochondrial-dependent fashion [25]. In line with this, PL analogs dramatically decreased the MMP (Figure 5B) and resulted in A549 cells apoptosis (Figure 3). All of the results in Figures 4 and 5 were partly or entirely reversed by NAC. These results also hinted that the anticancer activities of PL analogs were attributed to the ROS generation.

Collectively, this work elucidates that the Michael acceptor of lactam plays a major role in PL analogs' cytotoxicity. Whereas, the cinnamic acid unit, with strong electronwithdrawing or weak electron-donating groups partly contributed to that. The cysteamine mainly reacted with the $\mathrm{C} 2-\mathrm{C} 3$ double bond of PL analogs. PL analogs could irreversibly inhibit TrxR and result in ROS accumulation, which further disrupt redox imbalance, induce lipid peroxidation, lead to the loss of MMP, and ultimately result in A549 cell line cell death (Scheme 2). 


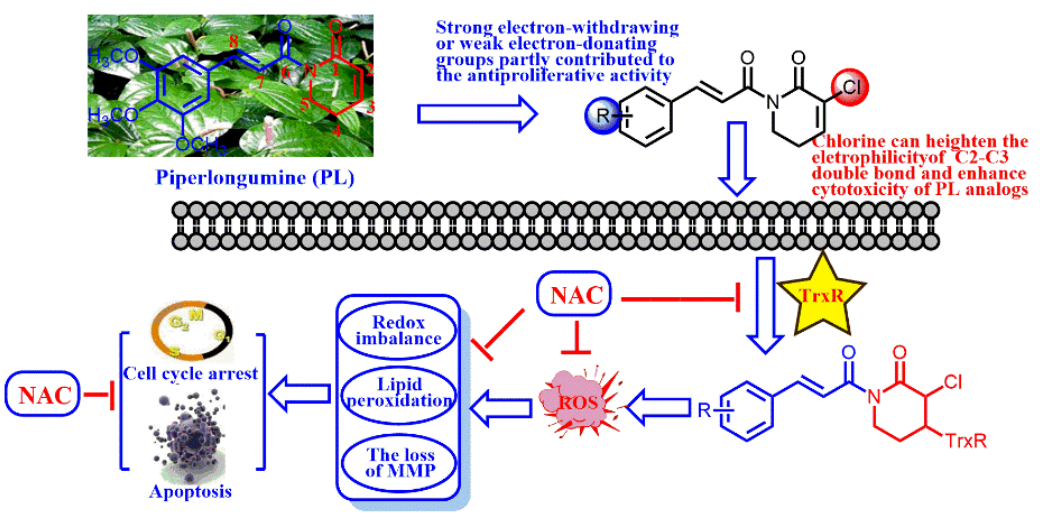

Scheme 2. Proposed mechanism underlying the cytotoxicity of PL-6.

\section{Materials and Methods}

\subsection{Materials}

Roswell Park Memorial Institute (RPMI)-1640 was from Hyclone. 3-(4,5-dimethylthiazol-2yl)-2,5-diphenyltetrazolium bromide (MTT), rhodamine $123,2^{\prime}, 7^{\prime}$-dichlorofluorescein diacetate, GSH and GSSG Assay kit, and thiobarbituric acid were purchased from Beyotime. The annexin V-FITC/PI apoptosis detection kit was from BD Biosciences. Substituted benzaldehyde, 2piperidone and piperlongumine were from EnergyChemical. All other chemicals were of the highest quality available.

\subsection{Synthesis of the PL Analogs}

4.2.1. The Preparation of Cinnamoyl Chloride (Intermediate 2)

The cinnamoyl chloride 2 was prepared according to previously reported methods [17]. Briefly, substituted aldehyde $(20 \mathrm{mmol})$ was condensed with malonic acid $(24 \mathrm{mmol})$ in the presence of piperidine $(1.2 \mathrm{~mL})$ to afford a crude solid. After, it was recrystallised from ethanol to afford corresponding cinnamic acids $\mathbf{1}$. Then, intermediate $\mathbf{1}$ (2 $\mathrm{mmol})$ reacted with oxalyl chloride $(6 \mathrm{mmol})$ in dry $\mathrm{CH}_{2} \mathrm{Cl}_{2}(4 \mathrm{~mL})$ to produce cinnamoyl chloride 2 .

\subsubsection{The Preparation of 3-Chloro-5,6-dihydropyridin-2(1H)-one (Intermediate 4)}

The intermediate 4 was acquired from 2-piperidone according to the previously reported procedure [17]. Briefly, the mixture containing 2-piperidone (5 mmol), phosphorus pentachloride $(15 \mathrm{mmol})$ and chloroform $(15 \mathrm{~mL})$ was refluxed for $12 \mathrm{~h}$. After cooling, adjusting $\mathrm{pH}$ to 9 , extracting with chloroform/methanol (10/1) and purifying by flash cloumn chromatography, the intermediate 3 was obtained with a white solid. The intermediate 3 (2.5 mmol) and lithium carbonate $(7.5 \mathrm{mmol})$ was dissolved in DMF (Dimethyl Formamide, $5 \mathrm{~mL}$ ) and heated to $120^{\circ} \mathrm{C}$ for $12 \mathrm{~h}$. After removing the solvent, the residue was extracted with chloroform and purified with cloumn chromatography to afford the intermediate 4 .

The mixture, containing intermediate 4 ( $2 \mathrm{mmol})$, cinnamoyl chloride 2 ( $2 \mathrm{mmol})$, triethylamine $(6 \mathrm{mmol})$ and dry $\mathrm{CH}_{2} \mathrm{Cl}_{2}(5 \mathrm{~mL})$, was stirred at room temperature for $24 \mathrm{~h}$. After extracting with ethyl acetate and purification by cloumn chromatography, the target product was obtained.

(E)-3-chloro-1-(3-(3-methoxyl-cinnamoyl))-5,6-dihydropyridin-2(1H)-one (PL-1): Yield 16.2\% (the yield is the reaction between intermediate 4 and cinnamoyl chloride 2 ), yellow solid, ${ }^{1} \mathrm{H}-\mathrm{NMR}\left(500 \mathrm{MHz},\left(\mathrm{CDCl}_{3}\right), \delta 7.74(\mathrm{~d}, J=16.0 \mathrm{~Hz}, 1 \mathrm{H}), 7.49(\mathrm{~d}, J=15.5 \mathrm{~Hz}, 1 \mathrm{H}), 7.28(\mathrm{t}\right.$, $J=8.0 \mathrm{~Hz}, 1 \mathrm{H}), 7.19(\mathrm{~d}, J=7.5 \mathrm{~Hz}, 1 \mathrm{H}), 7.09-7.11(\mathrm{~m}, 2 \mathrm{H}), 6.93(\mathrm{~d}, J=8.0 \mathrm{~Hz}, 1 \mathrm{H}), 4.09(\mathrm{t}$, $J=6.5 \mathrm{~Hz}, 2 \mathrm{H}), 3.85(\mathrm{~s}, 3 \mathrm{H}), 2.56-2.60(\mathrm{~m}, 2 \mathrm{H}) ;{ }^{13} \mathrm{C}-\mathrm{NMR}\left(125 \mathrm{MHz},\left(\mathrm{CDCl}_{3}\right), \delta 167.4,160.2\right.$, $158.8,143.5,139.9,135.1,127.8,127.2,120.3,120.1,115.3,112.1,54.2,40.6,24.2$. HRMS $m / z$ $\left(\mathrm{ES}^{+}\right):[\mathrm{M}+\mathrm{Na}]^{+} 314.0558$ (theor 314.0560). 
(E)-3-chloro-1-(3-(3-trifluoromethylphenyl)acryloyl-5,6-dihydropyridin-2(1H)-one(PL-2): Yield $12.6 \%$ (the yield is the reaction between intermediate 4 and cinnamoyl chloride 2), yellow solid, ${ }^{1} \mathrm{H}-\mathrm{NMR}\left(500 \mathrm{MHz},\left(\mathrm{CDCl}_{3}\right), \delta 7.81(\mathrm{~s}, 1 \mathrm{H}), 7.74(\mathrm{~d}, J=15.5 \mathrm{~Hz}, 1 \mathrm{H}), 7.74(\mathrm{t}\right.$, $J=8.5 \mathrm{~Hz}, 1 \mathrm{H}), 7.62(\mathrm{~d}, J=8.0 \mathrm{~Hz}, 1 \mathrm{H}), 7.52(\mathrm{~d}, J=15.5 \mathrm{~Hz}, 1 \mathrm{H}), 7.49(\mathrm{t}, J=7.5 \mathrm{~Hz}, 1 \mathrm{H}), 7.10$ $(\mathrm{t}, J=4.5 \mathrm{~Hz}, 1 \mathrm{H}), 4.09(\mathrm{t}, J=6.5 \mathrm{~Hz}, 2 \mathrm{H}), 2.57-2.61(\mathrm{~m}, 2 \mathrm{H}) ;{ }^{13} \mathrm{C}-\mathrm{NMR}\left(125 \mathrm{MHz},\left(\mathrm{CDCl}_{3}\right)\right.$, $\delta 168.2,161.5,142.5,141.3,135.7,131.6,131.4,129.4,128.2,126.7,124.9,123.1,122.8,41.8$, 25.3. HRMS $m / z\left(\mathrm{ES}^{+}\right):[\mathrm{M}+\mathrm{Na}]^{+} 352.0328$ (theor 352.0325).

(E)-3-chloro-1-(3-(3-fluorine-cinnamoyl))-5,6-dihydropyridin-2(1H)-one (PL-3): Yield 4.5\% (the yield is the reaction between intermediate 4 and cinnamoyl chloride 2), yellow solid, ${ }^{1} \mathrm{H}-\mathrm{NMR}\left(500 \mathrm{MHz},\left(\mathrm{CDCl}_{3}\right), \delta 7.68(\mathrm{~d}, J=15.5 \mathrm{~Hz}, 1 \mathrm{H}), 7.34-7.36(\mathrm{~m}, 2 \mathrm{H}), 7.26-7.28(\mathrm{~m}\right.$, $2 \mathrm{H}), 7.15(\mathrm{~d}, J=15.5 \mathrm{~Hz}, 1 \mathrm{H}), 7.08-7.11(\mathrm{~m}, 1 \mathrm{H}), 3.86(\mathrm{t}, J=6.0 \mathrm{~Hz}, 2 \mathrm{H}), 2.84-2.86(\mathrm{~m}, 2 \mathrm{H})$; ${ }^{13} \mathrm{C}-\mathrm{NMR}\left(125 \mathrm{MHz},\left(\mathrm{CDCl}_{3}\right), \delta 169.4,166.3,164.0,143.2,136.9,130.4,124.4,121.6,117.4\right.$, $117.2,114.8,114.6,45.4,20.3$. HRMS $m / z\left(\mathrm{ES}^{+}\right):[\mathrm{M}+\mathrm{Na}]^{+} 302.0360$ (theor 302.0358).

(E)-3-chloro-1-(3-(4-nitro-cinnamoyl))-5,6-dihydropyridin-2(1H)-one (PL-4): Yield 7.1\% (The yield is the reaction between intermediate 4 and cinnamoyl chloride 2), yellow solid, ${ }^{1} \mathrm{H}-\mathrm{NMR}\left(500 \mathrm{MHz},\left(\mathrm{CDCl}_{3}\right), \delta 8.23(\mathrm{~d}, J=8.5 \mathrm{~Hz}, 2 \mathrm{H}), 7.72-7.75(\mathrm{~m}, 3 \mathrm{H}), 7.56(\mathrm{~d}, J=16.0 \mathrm{~Hz}\right.$, $1 \mathrm{H}), 7.12(\mathrm{t}, J=4.5 \mathrm{~Hz}, 1 \mathrm{H}), 4.10(\mathrm{t}, J=6.0 \mathrm{~Hz}, 2 \mathrm{H}), 2.59-2.62(\mathrm{~m}, 2 \mathrm{H}) ;{ }^{13} \mathrm{C}-\mathrm{NMR}(125 \mathrm{MHz}$, $\left(\mathrm{CDCl}_{3}\right), \delta 167.8,161.5,148.5,141.5,141.1,140.9,128.9,128.1,125.5,124.1,41.8,25.3$. HRMS $m / z\left(\mathrm{ES}^{+}\right):[\mathrm{M}+\mathrm{Na}]^{+} 329.0304$ (theor 329.0305).

(E)-3-chloro-1-(3-(4-trifluoromethyl-cinnamoyl))-5,6-dihydropyridin-2(1H)-one (PL-5): Yield 3.7\% (the yield is the reaction between intermediate 4 and cinnamoyl chloride 2), yellow solid, ${ }^{1} \mathrm{H}-\mathrm{NMR}\left(500 \mathrm{MHz},\left(\mathrm{CDCl}_{3}\right), \delta 7.73(\mathrm{~d}, J=15.5 \mathrm{~Hz}, 1 \mathrm{H}), 7.66(\mathrm{t}, J=8.5 \mathrm{~Hz}, 2 \mathrm{H})\right.$, $7.62(\mathrm{t}, J=8.5 \mathrm{~Hz}, 2 \mathrm{H}), 7.53(\mathrm{~d}, J=15.5 \mathrm{~Hz}, 1 \mathrm{H}), 7.11(\mathrm{t}, J=4.5 \mathrm{~Hz}, 1 \mathrm{H}), 4.10(\mathrm{t}, J=6.5 \mathrm{~Hz}$, 2H), 2.58-2.61 (m, 2H); ${ }^{13} \mathrm{C}-\mathrm{NMR}\left(125 \mathrm{MHz},\left(\mathrm{CDCl}_{3}\right), \delta 167.0,160.3,141.2,140.2,137.1\right.$, $127.3,127.0,124.6,122.6,121.7,40.6,28.6,24.2$. HRMS $m / z\left(\mathrm{ES}^{+}\right):[\mathrm{M}+\mathrm{Na}]^{+} 352.0325$ (theor 3352.0328).

(E)-3-chloro-1-(3-(4-fluorine-cinnamoyl))-5,6-dihydropyridin-2(1H)-one (PL-6): Yield 7.1\% (the yield is the reaction between intermediate 4 and cinnamoyl chloride 2), yellow solid, ${ }^{1} \mathrm{H}-\mathrm{NMR}\left(500 \mathrm{MHz},\left(\mathrm{CDCl}_{3}\right), \delta 7.71(\mathrm{~d}, J=15.5 \mathrm{~Hz}, 1 \mathrm{H}), 7.57-7.59(\mathrm{~m}, 2 \mathrm{H}), 7.42(\mathrm{~d}, J=15.5\right.$ $\mathrm{Hz}, 1 \mathrm{H}), 7.09(\mathrm{t}, J=4.5 \mathrm{~Hz}, 1 \mathrm{H}), 7.05(\mathrm{t}, J=8.5 .5 \mathrm{~Hz}, 1 \mathrm{H}), 4.08(\mathrm{t}, J=6.5 \mathrm{~Hz}, 2 \mathrm{H}), 2.56-2.59$ $(\mathrm{m}, 2 \mathrm{H}) ;{ }^{13} \mathrm{C}-\mathrm{NMR}\left(125 \mathrm{MHz},\left(\mathrm{CDCl}_{3}\right), \delta\right.$ 168.4, 165.0, 161.5, 143.3, 141.1, 131.2, 130.3, 128.3, 121.0, 116.0, 41.7, 25.3. HRMS $m / z\left(\mathrm{ES}^{+}\right)$: $[\mathrm{M}+\mathrm{Na}]^{+} 302.0358$ (theor 302.0360).

\subsection{Cytotoxicity Assay}

The cytotoxicity of PL analogs against cancer cells was evaluated by the MTT assay [26]. In brief, A549 $\left(3 \times 10^{3} /\right.$ well $)$ and SK-OV3 $\left(5 \times 10^{3} /\right.$ well $)$ cells were treated with $\mathrm{PL}$ analogs for $48 \mathrm{~h}$ before measuring.

\subsection{Stability Test}

The stability of PL analogs in PBS buffer $(100 \mathrm{mM})$ at $25^{\circ} \mathrm{C}$ was surveied as previously reported [27]. Briefly, we observed the changes of maximun absorbance of the test compounds for $120 \mathrm{~min}$ at 10 -min intervals.

\subsection{Cell Cycle Analysis}

After incubation with the test compounds for $15 \mathrm{~h}$, A549 cells were collected, dyed with PI, and analyzed by flow cytometry as previously reported [26].

\subsection{Cancer Cells Apoptosis Assay}

After treatment with the test compounds for $18 \mathrm{~h}$, A549 cells were gathered, stained with FITC Annexin-V and PI, and analyzed with a flow cytometry as previously reported [28]. 


\subsection{ROS Detection}

A549 $\left(3 \times 10^{5}\right)$ cells were incubated with the tested compounds for $6 \mathrm{~h}$, then, the cells were collected, stained with DCFH-DA for $30 \mathrm{~min}$, and subsequently analyzed by flow cytometry as described previously [28].

\subsection{The Evaluation of Intracellular Redox Balance Levels}

After treatment with the test compounds for $6 \mathrm{~h}$, the cells were harvested, lysed, and assayed for determining the ratio of GSH/GSSG as previously reported [26].

\subsection{Determination of Lipid Peroxidation}

A549 cells $\left(3 \times 10^{5}\right.$ cells /well) were treated with the test compounds for $15 \mathrm{~h}$ before collecting. After lysing in RIPA buffer (RIPA Lysis Buffer), the supernatant was used to determine the lipid peroxidation as previously described [27].

\subsection{Measurement of Mitochondrial Membrane Potential}

Incubation with the test compounds for $15 \mathrm{~h}$, the cells were harvested, stained with Rhodamine 123, and analyzed by flow cytometry as previously reported [27].

\subsection{Electrophilicity Assessment by a Kinetic Thiol Assay}

The electrophilicity of $\mathbf{P L}$ analogs were evaluated by the pseudo-first-order assay and the results were expressed second-order rate constants $\left(k_{2}\right)$ as previously reported [29]. Briefly, the test compounds $(50 \mu \mathrm{M})$ were mixed with 100 -fold cysteamine at $25^{\circ} \mathrm{C}$, and monitored the decay of their wavelength maxima by using an ultraviolet-visible (UV-Vis) spectrophotometer. The second-order rate constants $\left(k_{2}\right)$ were obtained by plotting the pseudo-first-order constants vs. [cysteamine].

\subsection{Determination of the Reaction Site by Nuclear Magnetic Resonance $\left({ }^{1} H-N M R\right)$ and} High-Resolution Mass Spectrometry (HRMS)

${ }^{1} \mathrm{H}-\mathrm{NMR}$ spectra of PL-6 (30 mM in $d_{6}$-DMSO) after adding cysteamine (90 mM in $d_{6}$-DMSO) at set intervals $(0,1 \mathrm{~h})$ were recorded using a Bruker AV 500 spectrometer. After incubation 3 days, the reaction products were monitored by HRMS (Acquity UPLC I-Class/Xevo G2-XS QTOF) [17].

\subsection{Western Blot Analysis}

Briefly, after treatment with the test compounds for $18 \mathrm{~h}$, A549 cells were collected and lysed with ice-cold RIPA lysis buffer containing proteinase inhibitors. The expression of TrxR proteins after treatment with the test compounds was analyzed by Western blot as previously described [30].

\subsection{Statistical Analysis}

The data are expressed as the mean \pm S.D. of at least three independent experiments.

Data were analyzed using one-way analysis of variance (ANOVA) followed by the Dunnett test (comparing all drug treatment groups vs. control). The values were considered significant at $p<0.05 .^{*}: p<0.05 ;{ }^{* *}: p<0.01{ }^{* * *}: p<0.001$ compared with control.

Supplementary Materials: The data of the ${ }^{1} \mathrm{H} \mathrm{NMR},{ }^{13} \mathrm{C}-\mathrm{NMR}$ and HRMS of PL analogs are available in the supporting information.

Author Contributions: J.Y. conceived the project. J.Y. and G.-Y.L. designed the experiments. A.-L.S., P.-X.L. and Y.-L.S. synthesized the compounds. A.-L.S., Y.-M.L. and W.-W.M. performed the in vitro experiments. A.-L.S., W.-W.M., J.Y., R.-M.L. and G.-Y.L. wrote the initial manuscript draft. All authors have read and agreed to the published version of the manuscript.

Funding: This research was funded by the National Natural Science Foundation of China (Grant No. 81901420 and 21675071), Shandong Provincial Natural Science Foundation (Grant No. ZR2018LH022). 
Institutional Review Board Statement: Not applicable.

Informed Consent Statement: Not applicable.

Data Availability Statement: The data of the ${ }^{1} \mathrm{H}-\mathrm{NMR},{ }^{13} \mathrm{C}-\mathrm{NMR}$ and HRMS of PL analogs are available in the supporting information.

Acknowledgments: In this section, you can acknowledge any support given which is not covered by the author contribution or funding sections. This may include administrative and technical support, or donations in kind (e.g., materials used for experiments).

Conflicts of Interest: The authors declare no conflict of interest.

Sample Availability: Samples of the PL analogs are available from the authors.

\section{References}

1. Burgos, R.A.; Seguel, K.; Perez, M.; Meneses, A.; Ortega, M.; Guarda, M.I.; Loaiza, A.; Hancke, J.L. Andrographolide inhibits IFN- $\gamma$ and IL-2 cytokine production and protects against cell apoptosis. Planta Med. 2005, 71, 429-434. [CrossRef]

2. $\quad$ Fleck, J.D.; Betti, A.H.; Silva, F.P.D.; Troian, E.A.; Olivaro, C.; Ferreira, F.; Verza, S.G. Saponins from Quillaja saponaria and Quillaja brasiliensis: Particular Chemical Characteristics and Biological Activities. Molecules 2019, 24, 171. [CrossRef]

3. Fan, S.; Cao, Y.X.; Li, G.Y.; Lei, H.; Attiogbe, M.K.I.; Yao, J.C.; Yang, X.Y.; Liu, Y.J.; Hei, Y.Y.; Zhang, H. F10, a new camptothecin derivative, was identified as a new orally-bioavailable, potent antitumor agent. Eur. J. Med. Chem. 2020, $202,112528$. [CrossRef] [PubMed]

4. Li, X.Q.; Ren, J.; Wang, Y.; Su, J.Y.; Zhu, Y.M.; Chen, C.G.; Long, W.G.; Jiang, Q.; Li, J. Synergistic killing effect of paclitaxel and honokiol in non-small cell lung cancer cells through paraptosis induction. Cell. Oncol. 2020, 44, 135-150. [CrossRef] [PubMed]

5. Yadav, V.; Krishnan, A.; Vohora, D. A systematic review on Piper longum L.: Bridging traditional knowledge and pharmacological evidence for future translational research. J. Ethnopharmacol. 2020, 247, 112255. [CrossRef] [PubMed]

6. Bi, Y.; Qu, P.C.; Wang, Q.S.; Zhang, L.; Liu, H.L.; Luo, R.; Chen, X.Q.; Ba, Y.Y.; Wu, X.; Yang, H. Neuroprotective effects of alkaloids from Piper longum in a MPTP induced mouse model of Parkinson's disease. Pharm. Biol. 2015, 53, 1516-1524. [CrossRef]

7. Sucher, N.J.; Carles, M.C. A pharmacological basis of herbal medicines for epilepsy. Epilepsy Behav. 2015, 52, 308-318. [CrossRef]

8. Wang, H.; Jiang, H.; Corbet, C.; Mey, S.; Law, K.; Gevaert, T.; Feron, O.; Ridder, M.D. Piperlongumine increases sensitivity of colorectal cancer cells to radiation: Involvement of ROS production via dual inhibition of glutathione andthioredoxin systems. Cancer Lett. 2019, 450, 42-52. [CrossRef]

9. Zhou, J.F.; Huang, Z.X.; Ni, X.; Lv, C. Piperlongumine induces apoptosis and G2/M phase arrest in human osteosarcoma cells by regulating ROS/PI3K/Akt pathway. Toxicol. In Vitro 2020, 65, 104775. [CrossRef]

10. Zheng, J.; Son, D.J.; Gu, S.M.; Woo, J.R.; Ham, Y.W.; Lee, H.P.; Kim, W.J.; Jung, J.K.; Hong, J.T. Piperlongumine inhibits lung tumor growth via inhibition of nuclearfactor kappa B signaling pathway. Sci. Rep. 2016, 6, 1-13. [CrossRef]

11. Thongsom, S.; Suginta, W.; Lee, K.J.; Choe, H.; Talabnin, C. Piperlongumine induces G2/M phase arrest and apoptosis in cholangiocarcinoma cells through the ROS-JNK-ERK signaling pathway. Apoptosis 2017, 22, 1473-1484. [CrossRef]

12. Raj, L.; Ide, T.; Gurkar, A.U.; Foley, M.; Schenone, M.; Li, X.; Tolliday, N.J.; Golub, T.R.; Carr, S.A.; Shamji, A.F.; et al. Selective killing of cancer cells by a small molecule targeting the stress response to ROS. Nature 2011, 475, 231-234. [CrossRef] [PubMed]

13. Galadari, S.; Rahman, A.; Pallichankandy, S.; Thayyullathil, F. Reactive oxygen species and cancer paradox: To promote or to suppress? Free Radic. Biol. Med. 2017, 104, 144-164. [CrossRef] [PubMed]

14. Ma, X.Q.; Yu, M.X.; Hao, C.X.; Yang, W.H. Shikonin induces tumor apoptosis in glioma cells via endoplasmic reticulum stress, and Bax/Bak mediated mitochondrial outer membrane permeability. J. Ethnopharmacol. 2020, 263, 113059. [CrossRef] [PubMed]

15. Fang, J.G.; Lu, J.; Holmgren, A. Thioredoxin reductase is irreversibly modified by curcumin a novel molecular mechanism for its anticancer activity. J. Biol. Chem. 2005, 280, 25284-25290. [CrossRef]

16. Dai, F.; Liu, G.Y.; Li, Y.; Yan, W.J.; Wang, Q.; Yang, J.; Lu, D.L.; Ding, D.J.; Lin, D.; Zhou, B. Insights into the importance for designing curcumin-inspired anticancer agents by a prooxidant strategy: The case of diarylpentanoids. Free Radic. Biol. Med. 2015, 85, 127-137. [CrossRef] [PubMed]

17. Yan, W.J.; Wang, Q.; Yuan, C.H.; Wang, F.; Ji, Y.; Dai, F.; Jin, X.L.; Zhou, B. Designing piperlongumine-directed anticancer agents by an electrophilicity-based prooxidant strategy: A mechanistic investigation. Free Radic. Biol. Med. 2016, 97, 109-123. [CrossRef]

18. Adamsa, D.J.; Daia, M.; Pellegrinoa, G.; Wagnera, B.K.; Stema, A.M.; Shamjia, A.F.; Schreibera, S.L. Synthesis, cellular evaluation and mechanism of action of piperlongumine analogs. Proc. Natl. Acad. Sci. USA 2012, 109, 15115-15120. [CrossRef]

19. Hagmann, W.K. The many roles for fluorine in medicinal chemistry. J. Med. Chem. 2008, 51, 4359-4369. [CrossRef]

20. Liang, X.J.; Guan, Y.P.; Zhang, B.C.; Liang, J.; Wang, B.C.; Li, Y.; Wang, J. Severe immune-related pneumonitis with PD-1 inhibitor after progression on previous PDL1 inhibitor in small cell lung cancer: A case report and review of literature. Front Oncol. 2019, 9, 1437. [CrossRef]

21. Liu, J.B.; Hu, L.; Yang, Z.J.; Sun, Y.; Hoffman, R.M.; Yi, Z. Aurora-A/NF-kB signaling is associated with radio-resistance in human lung adenocarcinoma. Anticancer. Res. 2019, 3911, 5991-5998. [CrossRef] 
22. Qin, L.M.; Zhong, M.L.; Adah, D.; Qin, L.; Chen, X.P.; Ma, C.Q.; Fu, Q.; Zhu, X.P.; Li, Z.L.; Wang, N.N.; et al. A novel tumour suppressor lncRNA F630028O10Rik inhibits lung cancer angiogenesis by regulating miR-223-3p. J. Cell Mol. Med. 2020, 24, 3549-3559. [CrossRef]

23. Song, Y.X.; Zhou, B.; Du, X.Y.; Wang, Y.; Zhang, J.; Ai, Y.Q.; Xia, Z.J.; Zhao, G.F. Folic acid (FA)-conjugated mesoporous silica nanoparticles combined with MRP-1 siRNA improves the suppressive effects of myricetin on non-small cell lung cancer (NSCLC). Biomed. Pharmacother. 2020, 125, 109561. [CrossRef]

24. Kong, Q.; Beel, J.A.; Lillehei, K.O. A threshold concept for cancer therapy. Med. Hypotheses 2000, 55, 29-35. [CrossRef] [PubMed]

25. Hatai, T.; Matsuzawa AInoshita, S.; Mochida, Y.; Kuroda, T.; Sakamaki, K.; Kuida, K.; Yonehara, S.; Ichijo, H.; Takeda, K. Execution of apoptosis signal-regulating kinase 1 (ASK1)-induced apoptosis by the mitochondria-dependent caspase activation. J. Biol. Chem. 2000, 275, 26576-26581. [CrossRef]

26. Yang, J.; Mu, W.W.; Liu, G.Y. Synthesis and evaluation of the anticancer activity of bischalcone analogs in human lung carcinoma (A549) cell line. Eur. J. Pharmacol. 2020, 888, 173396. [CrossRef]

27. Liu, G.Y.; Zhai, Q.; Chen, J.Z.; Zhang, Z.Q.; Yang, J. 2,2'-Fluorine mono-carbonyl curcumin induce reactive oxygen speciesMediated apoptosis in Human lung cancer NCI-H460 cells. Eur. J. Pharmacol. 2016, 786, 161-168. [CrossRef]

28. Liu, G.Y.; Sun, Y.Z.; Zhou, N.; Du, X.M.; Yang, J.; Guo, S.J. 3,3'-OH curcumin causes apoptosis in HepG2 cells through ROSmediated pathway. Eur. J. Med. Chem. 2016, 112, 157-163. [CrossRef]

29. Shi, H.L.; Li, Y.; Ren, X.R.; Zhang, Y.H.; Yang, Z.; Qi, C.Z. A novel quinazoline-based analog induces G2/M cell cycle arrest and apoptosis in human A549 lung cancer cells via a ROS-dependent mechanism. Biochem. Biophys. Res. Commun. 2017, 486, 314-320. [CrossRef] [PubMed]

30. Ma, Y.Y.; Di, Z.M.; Cao, Q.; Xu, W.S.; Bi, S.X.; Yu, J.S.; Shen, Y.J.; Yu, Y.Q.; Shen, Y.X.; Feng, L.J. Xanthatin induces glioma cell apoptosis and inhibits tumor growth via activating endoplasmic reticulum stress-dependent CHOP pathway. Acta Pharmacol. Sin. 2020, 41, 404-414. [CrossRef] [PubMed] 